\title{
Czeczeńscy przywódcy religijni od XVIII do XIX w.
}

\section{Wstęp}

Drzywódcy religijni, tak jak polityczni odgrywali w historii i odgrywają 1 obecnie szczególną rolę w społeczeństwie lub w niektórych państwach na świecie. W przeszłości świat słyszał o przywódcach religijnych potrafiących poderwać nie tylko grupy, ale całe tłumy społeczeństwa do zrealizowania swoich celów. Autor ma tutaj na myśli Ajatollaha Chomeiniego, dzięki któremu doszło do znaczących zmian w państwie irańskim. Między innymi nastąpił przełom w postrzeganiu świata zachodniego nie tylko przez samych Irańczyków ale też przez pozostałych muzułmanów. Jeszcze wcześniej, przed wydarzeniami z Iranu (1979 r.), wyłania się postać pastora ze Stanów Zjednoczonych, Martina Luthera Kinga. Był to lider ruchu praw obywatelskich przy jednoczesnym działaniu na rzecz równouprawnienia Afroamerykanów, który poprzez swoją działalność dążył do zniesienia dyskryminacji rasowej w tym państwie. Skądinąd na obszarach dzisiejszej Czeczenii, Dagestanu czy Inguszetii znaczącą rolę w walce o wolność odegrali również przywódcy religijni. Przestrzeganie rosyjskiego prawa i panowanie Rosjan na ziemiach czeczeńskich czy też sąsiednich, doskwierało nie tylko samym Czeczenom, ale także pozostałym grupom etnicznym, zamieszkującym wówczas ziemie Kaukazu Północnego np. Inguszom czy Awarom. Zatem w opinii autora warto przedstawić osobistości , których rola w walce z Imperium Rosyjskim była nieoceniona. A tymi postaciami byli kolejno: Mansur Uszurma, Kazi mułła, Gamzat Bek oraz Osman Szamil.

Na zakończenie tytułem wstępu, autor chciałby dodać, iż prezentowanie sylwetek wyżej wspomnianych przywódców religijnych nastąpi w kolejności alfabetycznej. Jak zauważymy autor najwięcej uwagi poświęcił Mansurowi Uszurmie i Osmanowi Szamilowi, albowiem to ci dwaj przywódcy wraz ze swoimi grupami ludów kaukaskich najdłużej stawiali czoła armii Imperium Rosyjskiego i oddziałom kozackim. Przy tym, na temat 
Osmana Szamila, wydano i spisano najwięcej faktów i informacji z tej nierównej walki górali kaukaskich z Rosjanami wespół z Kozakami.

\section{Szejk Mansur Uszurma}

Mansur Uszurma był pierwszym przywódcą religijnym, który kierował północnokaukaskim ruchem oporu przeciwko obecności i ekspansji Imperium Rosyjskiego. Urodził się w 1732 r. w wiosce Ałdi niedaleko Sunży. Był wyznawcą i zwolennikiem sufizmu - bractwa Nakszanbandiji ${ }^{1}$, zaś niektóre źródła wskazują nawet na fakt, iż to on był założycielem bractwa Nakszanbandiji na ziemiach dzisiejszej Czeczenii. Mansur wychowywał się w Dagestanie ${ }^{2}$ w czasach ścisłego przestrzegania prawa islamskiego, a wraz z upływem lat, powrócił do Czeczenii, gdzie popierał zaprzestanie praktykowania rytuałów pogańskich i zastąpienia prawa adatu, szariatem. Zakazał również kultu zmarłych i między innymi palenia (tytoniu - w przyp. autora). Nie było to szczególnie łatwe na obszarach, w których to ludzie trzymali się starożytnych zwyczajów i przekonań, a tradycje islamskie, zwłaszcza w regionach górskich, nie były tak głęboko zakorzenione jak w sąsiednim Dagestanie. Pomimo tego wszystkiego udało mu się stworzyć ruch oporu wobec

1 Braterstwo nie pochodziło od wielkiej postaci sufi z Buchary, Baha ,al-Din Naqshaband (1318-1389), choć w tym wieku miał znaczącą rolę w nadawaniu aktywności tego braterstwa na dalsze lata. Inicjatorem bractwa był Khwaja Yusuf Hamdani (zm. 1141 r.), którego rekolekcje i jego grób, w Marv (w dzisiejszym Turkmenistanie), były znane jako Ka’ba Khurasan. Braterstwo kładzie nacisk na cichą modlitwę (zikr/dhikri khafi). Bez względu na pochodzenie, Nakszanbandiji najprawdopodobniej udało się stać się najbardziej dynamicznym i głęboko zakorzenionym bractwem sufi w Europie Wschodniej jako całości, i tak jest w obecnym czasie, a jego członków można znaleźć na Bałkanach i Turcji, w częściach Kaukazu i Rosji oraz wśród Tatarów na półwyspie krymskim. Prawdopodobnie jest to również Bośnia, gdzie po raz pierwszy w 1463 roku wybudowano w Sarajewie pierwsze tekke. Największe centrum miasta znajduje się niedaleko Fojnicy, w centralnej Bośni, gdzie jego tekke powstało w 1781 roku dzięki szachowi Husejnowi, który studiował w Muridiyya tekke, w Stambule. Oglavik tekke, w Bośni, był siedzibą szajcha Sirri Baby, który stał się sławny w całej Bośni za ilahis, jego pieśni boskiej pochwały, skomponowane w języku serbsko-chorwackim. Zmarł w 1846/7 r. W późniejszym czasie członkowie Nakszanbandiji stali się impulsem do wydawania ważnego czasopisma sufi, Sebi Arus, który został opublikowany w Sarajewie. Członkowie tego bractwa odegrali znaczącą rolę po stronie oporu bośniackiego w niedawnej wojnie przeciwko Serbom, w Bośni. Bractwa znajdują się także w innych miejscach Europy Wschodniej: w Dagestanie, Czeczenii, Kazaniu głównie wśród Tatarów. Nakszanbandija ukształtowała wiarę i kulturę wielu krajów Europy Wschodniej, która jest solidarna z sunnitami w swoich przekonaniach. Za: H.T. Norris, Popular Sufism in Eastern Europe. Sufi brotherhoods and the dialogue with Christianity and 'hererodoxy', Nowy Jork 2006, s. 135.

2 A. Askerov, Historical Dictionary of the Chechen Conflict, Lanham 2015, s. 2. 
wojsk rosyjskich na Kaukazie, który z czasem przybrał zorganizowaną formę. Popularność i władza Mansura wśród Czeczenów oraz innych narodów budziła zaniepokojenie obecnych tam wojsk rosyjskich, które poprzez różnego rodzaju komunikaty, nawoływało ludzi wierzących do praktykowania swojej religii oraz do odrzucenia wierzeń dyktowanych przez Mansura. Zdaniem Rosjan jawiły się one jako fałszywe nauki islamskie. Rosyjska propaganda usiłowała oczernić postać Mansura, obrazując go i opisując jako osobę o negatywnym obliczu ${ }^{3}$. Na nic się to wszystko zdało, gdyż w roku 1784, Mansur został ogłoszony „szejkiem”, a następnie „imamem”. Należy wskazać w tym miejscu, iż zgodnie z tradycją Mansur był pierwszym liderem, który uznał, że zjednoczony front na Północnym Kaukazie jest odpowiedzią na rosyjskie wkroczenie na ziemie miejscowej ludności. W owym czasie ogłosił on "Świętą wojnę” i rozpoczął zmasowane ataki na wojska carskie. Taka pierwsza poważna wzmianka nt. jego osoby w historii Północnego Kaukazu, jako przywódcy narodów kaukaskich datowana jest na rok $1785^{5}$. W opinii autora warto zwrócić uwagę na fakt, że istnieje również inna wersja, wskazująca przyczynę ogłoszenia owej „świętej wojny”. Otóż, jak podaje Ali Askerow: „W połowie 1785 r. rosyjski car wysłał pułkownika Pieri na Kaukaz, aby wygrać z Mansurem Uszurmem. Jego nieudana próba posłużyła za punkt wyjścia do ogłoszenia świętej wojny przeciwko Imperium Rosyjskiemu. Ogłaszając świętą wojnę, Mansur zainicjował próbę zjedno-

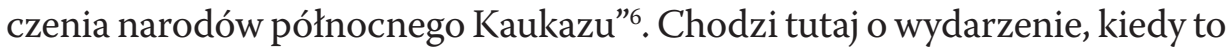
rosyjskie wojska zostały wysłane do miasta Ałdi, aby pojmać Mansura. Do schwytania nie doszło. Wojska rosyjskie zniszczyły jedynie wioskę, a w drodze powrotnej zostały zaatakowane przez Mansura i jego oddział. W bitwie pod Sunżą zginęło ponad 600 rosyjskich żołnierzy ${ }^{7}$. Pośród nich był także pułkownik Pieri. Mansur i jego ruch oporu wzbudzili szacunek ze strony przeciwników z całego Północnego Kaukazu ${ }^{8}$ Wcześniejsze szybkie sukcesy Mansura, przyciągnęły dużą liczbę wojowników Dagestanu (we wschodniej części Kaukazu Północnego - w przyp. autora) i Kabardy (w zachodniej

3 Ibidem.

4 A. Jaimoukha, The Chechens. A handbook, Londyn-Nowy Jork 2005, s. 40-41.

5 Ibidem, s. 41.

6 A. Askerov, op.cit., s. 2.

7 Ibidem.

8 Ibidem. 
części Kaukazu Północnego - w przyp. autora), aby zjednoczyć się w celu wspólnej walki pod jednym sztandarem. Marginalizując jednak sytuację, jaka panowała w mieście Kizliar w sierpniu 1785 roku, nie przeczuwał, że tego samego roku, w listopadzie zostanie pokonany przez oddziały dowodzone przez generała Pawła Potiomkina w Kabardzie. Porażki te oznaczały pasmo nieszczęść w jego karierze wojskowej. Tym samym, Kabardowie oraz Dagestańczycy, a nawet ludzie bliscy Mansurowi pozostawili go i opuścili szeregi jego oddziałów. Po tych wszystkich ciosach, Mansur schronił się w zachodniej części Czerkiesji, gdzie na nowo zajął się tworzeniem oddziałów oraz koordynowaniem działaniami przy współudziale z Imperium Osmańskim. Tymczasem Rosjanie wzmacniali swe osady a także wycofali siły z Gruzji i przenieśli je w okolice Tereka. W roku 1786, Rosjanie opuścili miasto Władykaukaz, który nie został jeszcze do końca rozbudowany (aż do roku 1803)9. Taką samą wersję przytacza A. Askerow, który wspomina, iż po przegranej walce Mansura na obszarach Kabardii, Rosjanie dokonywali wzmocnień osady, a w tym samym czasie caryca Katarzyna II Wielka wycofała rosyjskie siły z Gruzji, by ustanowić nową bazę na linii rzeki Terek ${ }^{10}$. W opinii tego samego autora w 1786 r., Rosjanie opuszczali twierdzę we Władykaukazie, który nie został aż do 1803 r. w pełni zajęty przez Rosjan ${ }^{11}$. Z kolei Mansur Uszurma wykorzystał aktywne/istniejące bractwa sufich do mobilizacji przeciwko prawosławnym najeźdźcom z Imperium Rosyjskiego. Podczas wojny religia, a zwłaszcza suficki islam - a konkretnie bractwo Nakszbandijja, dostarczył ideologicznych przesłanek dla pierwszego politycznego zjednoczenia tegoż regionu ${ }^{12}$. W tym miejscu warto zaznaczyć, iż pojawienie się Mansura nie wzięło się znikąd. Ów przywódca religijny objawił się nam jako głównodowodzący powstaniem przeciwko kolonizatorom rosyjskim pod koniec XVIII w. Jak do tego doszło? Otóż należy wskazać na fakt, iż fundamentalnymi celami polityki prowadzonej wobec Kaukazu Północnego przez Katarzynę II Wielką były środki bezpośrednie, czyli siły zbrojne $^{13}$.

\footnotetext{
9 A. Jaimoukha, op.cit.

10 A. Askerov, op.cit., s. 3.

11 Ibidem.

12 G. Jemalianowa, Russia and Islam. A Historical Survey, Nowy Jork 2002, s. 48 [ebook].

13 I. Rybkin, Consent in Chechnya, consent in Russia, [b.m.w.] 1998, s.21.
} 
W 1777 roku Rosjanie na Kaukazie Północnym utworzyli swoje rządy. Zainicjowali budowę serii fortec oraz stworzyli kozackie wioski, które były lokalizowane na odcinku od Mozdoku do Azowa ${ }^{14}$. Jednak jak wskazuje Hans Krech, rzeczywista, krwawa wojna o niepodległość plemion górskich przeciwko Rosjanom rozpoczęła się już w 1772 r. pod dowództwem właśnie czeczeńskiego bohatera narodowego Mansura Uszurmy, nazywającego siebie od 1782 r. Mahdim ${ }^{15}$ (zbawicielem). Wtedy to (1772 r.) po raz pierwszy wezwał naród czeczeński do dżihadu, świętej wojny przeciwko Imperium Rosyjskiemu ${ }^{16}$. Dodajmy, iż dominacji carskiej na ziemiach czeczeńskich i innych ludów kaukaskich nie było końca. Kozakami i ich rodzinami zasiedlano całe połacie ziem, tworząc stanice oraz różne fortece obronne. Zajmowane ziemie były bogate w zasoby naturalne. Warto wskazać również, iż kluczowe w tej kolonizacji było utworzenie oddziału Kozaków nadwołżańskich w 1777 r. Wraz z nimi przybyło 700 rodzin, które rozmieszczono w 5 wioskach między Mozdokiem a Stawropolem. Z kolei osoby, które sprzeciwiały się obecności carskich wojsk, w 1778 r. przesiedlono z ich dotychczasowych ziem. Było to 4640 osób ${ }^{17}$. Już w $1781 \mathrm{r}$. Imperium Rosyjskie, używając pewnej sztuki dyplomatycznej i dóbr naturalnych, uzyskało władzę nad podporządkowanymi terenami zamieszkałymi przez Czeczenów i Inguszów. Zaś w 1785 r. generałowie rosyjscy zakończyli budowę wojskowej linii wzdłuż Tereka i Kubania, czyli był to odcinek od Mozdoku po Władykaukaz. Spowodowane było to tym, iż rosyjskie oddziały miast prowadzić współpracę z miejscowymi książętami i podporządkować ich w sposób pokojowy, dokonywały blokady północnej i zachodniej części granicy Czeczenii. Takie nieoczekiwane wyzwanie dla nawiązanych relacji między Rosjanami a ludami Kaukazu, spowodowało wybuch gniewu i oburzenia ze strony Czeczenów oraz Inguszy. Wówczas pojawiło się kolejne, potężne powstanie pod przywództwem

14 T.M. Barrett, At the edge of Empire. The Terek Cossacks and the North Caucasus frontier 1700-1860, Boulder 1999, s. 40.

15 Zapowiadany islamski odkupiciel opisany w niektórych islamskich tradycjach, ale nie wspomniany w Koranie. Za: R. Lacey, Inside the kingdom: Kings, clerics, modernists, terrorists, and the struggle for Saudi Arabia, Londyn 2009, s. 339.

16 H. Krech, Der russische Krieg in Tschetschenien (1994-1996). Ein handbuch: Mit eine Sicherheitskonzept zur Einbindung der Russischen Föderation in die NATO und die Europaische Union, Berlin 1997, s. 11.

17 T.M. Barrett, op.cit., 40-41. 
Mansura ${ }^{18}$. Właśnie rok 1785 r. to punkt kulminacyjny dla zbuntowanych ludów kaukaskich wobec obecności armii carskiej i oddziałów kozackich. Kolejny nacisk na kolonizację carską, spowodował, iż pojawił się pierwszy na tak dużą skalę opór północnokaukaski przeciw Imperium Rosyjskie$\mathrm{mu}^{19}$. Warto dodać jeszcze, iż H. Krech wzmiankuje, że przedstawiana postać współpracowała z Imperium Osmańskim ${ }^{20}$, które było obecne na północnym wybrzeżu Morza Czarnego w fortecach: Anapy, Suchumi, Poti, Anaklii oraz w innych miastach. Na przykład twierdza w Anapie, która została zbudowana w 1784 r., służyła jako baza, z której Turcy utrzymywali swoje polityczne i handlowe kontakty z ludźmi zamieszkującymi Kaukaz Północny. Był to centralny etap, w którym w tamtym czasie toczyła się walka o władzę między Rosją a Imperium Osmańskim. Rosjanie uważali miasta przybrzeżne będące pod kontrolą turecką za kompromitującą strategię wojenną, która miała zniszczyć Czerkiesów, poprzez zajęcie portów obronnych. Z kolei w 1787 r. pomiędzy Rosjanami a Turkami doszło do wzmożonych walk, zaś we wrześniu Rosjanie pokonali połączone i zmobilizowane oddziały dowodzone przez Mansura, złożone z Czerkiesów i Nogajów, które następnie schroniły się w Anapie, mieście, które zostało zaatakowane w latach 1788 i $1789^{21}$. Ważną w tym momencie wzmianką winien być fakt, że od 1787 r. Czerkiesi wspierali Mansura w walkach $\mathrm{z}$ wojskami carskimi i toczyli je nawet po jego śmierci, do 1864 roku $^{22}$. Askerow, podaje, iż większość walczących pod dowództwem Mansura pochodziła z Dagestanu i Czeczeni ${ }^{23}$, ale mówi się także, że inni buntownicy walczący wraz z Mansurem byli zwolennikami mistyczno-purytańskiej sekty islamskiej, miurydyzmu²4.

Mansur Uszurma, to przywódca religijny będący prekursorem imamów, którzy w przyszłości, nawet 40 lat później podejmowali walkę na Kaukazie Północnym. Dokonując oceny z perspektywy historycznej, jego sukcesy są bardzo wartościowe, zaś on sam został obwieszczony legendą,

\footnotetext{
18 I. Rybkin, op.cit., s. 21.

19 Ibidem. .

20 H. Krech, op.cit., s. 11.

21 A. Jaimoukha, op.cit., s. 41.

22 H. Krech, op.cit.

23 A. Askerov, op.cit., s. 2.

24 H. Krech, op.cit., s. 11.
} 
okryty dobrą sławą. Tym samym został oficjalnie uznany za bohatera narodowego, gdy tylko Czeczeni odzyskali wolność dwa wieki później ${ }^{25}$. Warto dodać jeszcze, iż od roku 1785, aż do schwytania w Anapie w 1791 r., Mansur Uszurma, który głosił świętą wojnę przeciw Rosjanom, potrafił dowodzić i stawiać czoła tysiącom żołnierzy armii carskiej, podczas gdy swoich bojowników miał dosłownie garstkę. W skrajnych chwilach, odziały Mansura liczyły tylko 5000 walczących, zaś liczby zabitych żołnierzy ze strony sił carskich były ogromne. Na przykład w walkach niedaleko miasta Ałdami w 1785 r. liczba zabitych wynosiła 1500 (Z kolei strona czeczeńska straciła 300 walczących) ${ }^{26}$. Takie zachowanie może świadczyć o jednym; o sile omawianej postaci. Mansur wraz ze swoimi ludźmi zaatakował Kizlar (1785 r.), zmusił Rosjan do opuszczenia Władykaukazu oraz wielu innych fortyfikacji w górnym regionie Tereka ${ }^{27}$. Wspominany wcześniej Askerow podaje z kolei, iż po wielu udanych bitwach, Mansur poniósł klęskę, kiedy próbował zaatakować terytoria, gdzie wówczas przebywało dość liczne wojsko rosyjskie i nie zdołał tym samym zdobyć twierdzy $\operatorname{Kizliar}^{28}$. Nie podcięło mu to w żadnym wypadku skrzydeł i nadal organizował ataki na rosyjskich kolonizatorów ${ }^{29}$. Takie zachowanie mogło być następstwem żądzy zemsty na carskiej armii za podbój ziem kaukaskich i wprowadzenie rosyjskiej jurysdykcji na ziemiach zamieszkałych przez narody północnokaukaskie. Z drugiej strony Mansur po nielicznych wygranych potyczkach z armią carską nie przewidział dalszych konsekwencji swojej aktywności wojskowej. Nadszedł bowiem czas, kiedy to strona carska odpowiedziała na jego wojowniczą aktywność, ściągając regularną armię i Kozaków, aby przeciwstawili się powstaniu. Wówczas mała grupa walczących pod przywództwem Mansura musiała skonfrontować swoje siły z ogromną liczbą wojsk Imperium Rosyjskiego oraz oddziałami Kozaków, których głównym celem walki było nie tylko zwycięstwo, ale schwytanie przywódcy tych niepokornych i krnąbrnych oddziałów ludów północnokaukaskich. Można powiedzieć, że w tym momencie dobra passa

\footnotetext{
25 A. Jaimoukha, op.cit., s. 41.

26 T.M. Barrett, op.cit., s. 41.

27 Ibidem.

28 A. Askerov, op.cit.

29 T.M. Barrett, op.cit.
} 
dla Mansura zaczęła dobiegać końca, albowiem powstanie wzniecone pod jego przywództwem w roku 1787 zaczęło tracić na sile. W konsekwencji w roku 1791, Mansur został pojmany przez rosyjskie wojska i uwięziony w twierdzy Shlisselburg w Sankt Petersburgu, gdzie zmarł w kwietniu $1794 \mathrm{roku}^{30}$. Następnie jak podaje A. Askerow jego ciało w sposób dyskretny zostało spalone i złożone na Prieobrażenskiej górze. Natomiast słynny sowiecki historyk, Michaił Pokrowski nazwał szejka Mansura, pierwszym rewolucjonistą na Kaukazie, który dowodził antycarskim i antykolonialnym ruchem złożonym z ludzi północnokaukaskich. Mansur, religijny, wojskowy i polityczny lider górali północnokaukaskich stał się narodowym bohaterem Czeczenów oraz Inguszów ${ }^{31}$.

\section{Mohamed Ghazi}

Podjęte ruchy oporu kierowane przez sufickich imamów przeciwko carskiemu uciskowi na Kaukazie Północnym mogą być podzielone na trzy fazy. Pierwsza obejmowała czas dojścia do władzy pierwszego i drugiego imama, Kazi mułły, czyli Mohameda Ghaziego (1825-1832) oraz Gamzata beka (1832-1834) i imama Szamila. Druga faza to okres, podczas którego Szamil święcił największe sukcesy militarne przeciwko Imperium Rosyjskiemu, a jego władza trwała od 1840 do 1849 r. Z kolei ostatnia faza przypadająca na okres lat 1850-1885, ukazała stopniową erozję potęgi Szamila i brutalnego ujarzmienia ludów północnokaukaskich. Wracając do omawiania niniejszego przywódcy religijnego to warto rozpocząć od wzmianki, iż Ghazi Mohamed ibn Ismail z Dagestanu urodził się w Gimri w Dagestanie na początku lat 70. XVIII w. Na polecenie szejka Mohammeda Jaragskiego dokooptowany do sufickiego bractwa Nakszbandijja. Zgodnie z tradycją, Ghazi wezwał w 1828 r. do zjednoczenia się Czeczenów i ludów pochodzących z Dagestanu, a także kaukaskich górali, którzy mieli przestrzegać swoje rodzime prawo a nie narzucone, rosyjskie. Ów Ghazi ogłosił wojnę przeciwko Rosji wkrótce po tym, jak ogłoszono go imamem i jednocześnie przywódcą ludów północnokaukaskich w 1829 r. ${ }^{32}$

\footnotetext{
30 I. Rybkin, op.cit., s. 22.

31 A. Akserov, op.cit., s. 211.

32 A. Jaimoukha, op.cit., s. 43.
} 
Zaś w 1830 roku Hamza (Gamzat bek), uczeń Ghaziego Mohammada, dowodził kilkoma atakami przeciwko rosyjskim wojskom wzdłuż linii kaukaskiej. Wczesne sukcesy spowodowały, iż oddziały Ghaziego zyskały wielu zwolenników. W maju 1830 r. wysłał jednego ze swych zastępców, szejka Abdallaha z Ashilti do Czeczenii, aby ten koordynował atakami wespół z Czeczenami, którzy byli napędzani spiralą nienawiści w następstwie rosyjskiego okrucieństwa i tym samym zawarli sojusz z imamem. Następnie w miesiącach październik i listopad 1830 r. Ghazi zaatakował kilka fortec, w tym w mieście: Kizliar, Tarki i Nazraniu. Rosyjski dowódca Wieljaminow (Iwan - w przyp. autora) przeprowadził brutalną kampanię na początku 1831 r., w wyniku której zniszczono około 35 wiosek czeczeńskich $^{33}$. W czerwcu $1831 \mathrm{r}$. Abdallah położył kres skutecznemu oblężeniu pod Wniezapnają. Wówczas rosyjskimi oddziałami przewodził Emmanuel (Gieorgij - w przyp. autora), dowódca wojsk, ulokowanych na kaukaskiej linii, który wycofał się z oblężonej twierdzy 10 lipca 1831 r. Jednak wciąż kontynuował ataki na osobę Ghaziego. Ten, stosując taktykę ukrywania się w gęstym lesie w pobliżu aułu Aktasz, doprowadził do zwycięstwa nad wojskami dowodzonymi przez Emmanuela, który w wyniku ataku stracił setki swoich ludzi. Victoria wzmocniła reputację imama Ghaziego, wokół którego pojawiła się już spora liczba zwolenników, a nawet zmobilizowała część Inguszów, którzy słynęli z pacyficznego nastawienia w czasie tej wojny ${ }^{34}$. We wrześniu $1831 \mathrm{r}$. Emmanuel został zastąpiony przez Wieljaminowa, który do końca tegoż roku zniszczył kolejnych kilka wiosek czeczeńskich. W międzyczasie, w październiku 1831 r., car Mikołaj I (panujący w latach 1825-1855) mianował barona Grigorija Rosena na funkcję naczelnego dowódcy korpusu kaukaskiego. W następnym roku, Ghazi atakuje okolice: Groznego, Władykaukazu, Wniezapnaji, Derbentu i niektórych gruzińskich regionów. Pod koniec lipca 1832 r. do początku sierpnia tego samego roku, Rosen i Wieljaminow prowadzili oddzielne kampanie zbrojne przeciwko Inguszom i Karabułakom, niszcząc w ten sposób około 25 wiosek. W połowie sierpnia dwa oddziały, połączone zostały w jeden dywizjon liczący około 20000 żołnierzy, a priorytetem ich działań miało być wówczas zniszczenie niepokornej Czeczenii. Zaniepo-

\footnotetext{
33 Ibidem.

34 Ibidem., s. 43-44.
} 
kojony taki stanem rzeczy Imam, aby uwolnić swoich pobratymców zdecydował się w dniu 31 sierpnia na atak na jednostkę kozacką, liczącą 500 wojskowych, zabijając i raniąc prawie jedną trzecią jednostki. Jednocześnie zdobył dwie armaty. Z kolei 10 września, Ghazi niezdolny do kierowania atakami wycofał się do Gimri. Tutaj warto wspomnieć, iż troska o losy narodu spowodowała, że zainicjował on procesy pokojowe, które zostały odrzucone przez Klugenau (generała - w przyp. autora), ówczesnego dowódcy rosyjskich wojsk. Odrzucenie pokoju, przyspieszyło ze strony imama umocnienia pozycji w Gimri. W dniu 29 października 1832 r., Rosen zaatakował Gimri, zabijając imama i niemal całkowicie wyparł jego siły. Przeżyło niewielu partyzantów, a wśród nich, mimo poważnych obrażeń znalazł się Szamil. W kontekście dalszych wydarzeń historycznych można w tym momencie zaryzykować stwierdzeniem, iź śmierć Ghaziego nie doprowadziła do końca katastrofalnej wojny z narodami kaukaskimi, jak spodziewali się tego Rosjanie. Wkrótce Hamzat, kolejny Awar z Dagesta$\mathrm{nu}$, został ogłoszony nowym imamem i to on prowadził dalsze walki z rosyjskimi najeźdźcami ${ }^{35}$.

\section{Kazi mulła}

Kazi mułła zasłynął z dowodzenia najgłośniejszym atakiem/rajdem na główne miasto fortowe, Kiźliar w listopadzie 1831 r., gdzie zginęło 126 osób po stronie wroga, zaś 168 osób wzięto do niewoli; przy czym zrabowano 500 tysięcy rubli i dobra materialne z domostw oraz kościołów. Według szacunkowych ocen mieszkańców miasta siły grupy dowodzonej przez Kazi Muhammada oscylowały gdzieś pomiędzy 800 a 2000 buntownikami ${ }^{36}$. Kończąc dość krótkie omawianie aktywności niniejszego dowódcy północnokaukaskich buntowników, w tym Czeczenów, należy raz jeszcze podkreślić, iż Kazi mułła w sposób niezwykły i z ogromnym zaangażowaniem prowadził walki oporu przeciwko rosyjskim kolonizatorom na Kaukazie Północnym. Kazi Muhammad to lider górskich plemion buntowników w walce przeciwko Rosjanom. Zginął w 1832 r. Do jego uczniów należał urodzony w 1797 r. Szamil, Awar, który w 1834 r. był

\footnotetext{
35 Ibidem., s. 44.

36 T.M. Barrett, op.cit., s.157.
} 
kolejnym imamem i dowodził oddziałami, czy też grupami ludzi z Kaukazu Północnego ${ }^{37}$.

\section{Gamzat Bek}

Hamza Bek ibn ${ }^{38}$ Ali Iskandar Bek al-Hutsali (Znany jako Gamzat bek) urodził się w 1789 r. ${ }^{39}$ To kolejny, drugi imam, który dowodził ludami północnokaukaskimi, obejmując z powodzeniem przywództwo po przywołanym wcześniej Kazi Mulle. Był wychowywany pod okiem muzułmańskich dostojników religijnych i stał się zwolennikiem sufickiego islamu. W 1834 r. Gamzat bek zaatakował Chanat Awarski, którzy wspierali Rosjan w Dagestanie i zmobilizowali się do zdobycia stolicy Awarów ${ }^{40}$. W 1833 r. Gamzat bek, podobnie jak wcześniej Ghazi, złożył Rosjanom propozycję rozejmu, w zamian za możliwość wprowadzenia prawa szariatu na tych terenach. Rosen nie tylko odrzucił tę propozycję, ale także wezwał również przywódców awarskich, aby schwytali i przekazali władzom carskim Gamzata $^{41}$. Ale niezłomny Gamzat formując coraz to nowe wyzwania doprowadził do zintensyfikowania walk zbrojnych przeciwko wojskom rosyjskim $^{42}$. Wygrana nad rosyjskimi wojskami, spowodowała iż przejęli oni w ten sposób władzę nad całym Dagestanem ${ }^{43}$. Z kolei w 1834 r. zwolennicy lokalnych chanów dokonali mordu na Gamzacie beku ${ }^{44}$. A. Jaimoukha, doprecyzował tę śmierć, iż miała ona miejsce we wrześniu, zaś motywem śmierci była chęć zemsty. W kilka dni później nowym imamem ogłoszono Szamila ${ }^{45}$. Tak więc, po śmierci Gamzata beka, Szamil został trzecim imamem Północnego Kaukazu ${ }^{46}$.

37 H. Krech, op.cit., s. 11.

38 „ibn” - Oznacza „syn od” i jest używane przed właściwym imieniem wskazującym na ród/pochodzenie; „Bint” oznacza „córka od”. Za: Saudi Arabia. A modern reader, red. C. Winberg, Indianapolis 2005, s.194.

39 A. Jaimoukha, op.cit., s. 45.

40 A. Askerov, op.cit., s. 115.

41 A. Jaimoukha, op.cit.

42 Ibidem.

43 A. Askerov, op.cit.

44 A. Jaimoukha, op.cit.

45 Ibidem.

46 A. Askerov, op.cit. 


\section{Osman Szamil}

Od roku 1834, kiedy to ludy północnokaukaskie były dowodzone przez Szamila (Awara z pochodzenia), wojna z Imperium Rosyjskim nabrała długotrwałego charakteru. Warto wskazać na kilka w opinii autora istotnych faktów z życia Osmana Szamila. Po pierwsze, prawdziwe imię Szamila, to Ali. Dopiero w dalszej perspektywie czasu nastąpiła zmiana i zaczął przedstawiać się jako Szamil. „To było nazwisko jednego z proroków Bek-Izraela" ${ }^{47}$. Drugim czynnikiem wartym odnotowania jest fakt, iż Szamil był jednym z politycznych, wojskowych i duchowych liderów kaukaskich muzułmanów w XIX w. Imam Szamil prowadził (muzułmanów - w przyp. autora) do walki przeciwko rosyjskiej inwazji na Kaukazie Północnym. Posiadał wyrafinowane idee polityczne, według których starał się zbudować scentralizowane państwo (imamat), którego brakowało kaukaskim góralom. I po trzecie, Szamil, urodził się w 1797 roku w małym aule, Gimri, które leży w dzisiejszym Dagestanie ${ }^{48}$. Szamil studiował religię, język arabski oraz logikę. Imam Szamil i Kazi mułla w czasach dzieciństwa byli przyjaciółmi i razem studiowali. Z kolei w roku 1832, Kazi mułła ginie w walce w Gimri, zaś imam Gamzat bek przejmuje jego rolę. Natomiast Szamil był liderem w walce przeciwko Rosjanom od 1834 r. po śmierci Gamzata beka, który został zabity przez lokalnych naibów ${ }^{49}$. Szamil otrzymał szeroką wiedzę duchową na temat muzułmanów i był fizycznie silny. Wychowany w sposób spartański, odważny i zdecydowany. Prowadząc wojnę z Rosją, nie czuł żadnych patologicznych nienawiści do przeciwnika. Pisał on: „Na samym początku zwróciłem się do nich (Rosjan), starając się powiedzieć, że między mną a rosyjskim Padyszachem (powinno być) zawarto rozejm i nie zostanie odwołany, póki żyję" ${ }^{50}$. Uderzającą cechą wojen prowadzonych przez Szamila, która była często powtarzana, była ekstremalna wytrzymałość oporu, a przede wszystkim jej zdumiewająca zdolność do powrotu do stanu sprzed ataków, które mogły się wydawać przegrane.

\footnotetext{
47 I. Rybkin, op.cit., s. 25.

48 A. Askerov, op.cit., s. 120.

49 Ibidem.

50 I. Rybkin, op.cit., s. 26.
} 
Oznaczało to również istotną różnicę w porównaniu z wcześniejszym niepowodzeniem Mansura Uszurmy, który trzymał się swych zwolenników w trudnych dla nich czasie. Rosjanie dwukrotnie przypuszczali, iż wyszli zwycięsko z prowadzonych walk. Pierwszy przypadek miał miejsce w roku 1832 podczas szturmu przeprowadzonego na Gimri, gdzie doszło do zabicia Kazi mułły, i skąd Szamil, choć ciężko ranny cudem uciekł. Drugi przypadek, gdy w roku 1839, Rosjanie walczyli przy twierdzy Achulgo i zabili wielu jego najbliższych wojowników, zaś sam Szamil, ciężko raniony, z najmłodszym synem na plecach po raz kolejny uciekł. Najstarszy syn Szamila wówczas został zakładnikiem Rosjan. Po raz kolejny jego zwolennicy zebrali się i wznowili wspólną walkę. Młody rosyjski oficer, Dmitrij Miliutin (późniejszy minister wojny) opisywał z niechętnym zachwytem obronę samobójczą jednej wioski (w Dagestanie, a nie w Czeczenii) przez wojowników dowodzonych przez Szamila (uczniów i zwolenników) w taktyce wojennej, która była powtórzona ponownie w Groznym w ciągu następnych dwóch lat:

O 9 rano nasi żołnierze zajęli już większą część wsi, a nawet domy, w których miurydzi nadal bronią się, a rozlew krwi ma miejsce cały dzień, aż po mrok. Jedynym sposobem na przepędzenie miurydów $\mathrm{z}$ domostw było zrobienie dziur w dachach i rzucanie do ich środka palących się substancji. Zazwyczaj były to rozpalone drewniane belki.

Nawet mimo tego, pozostawali oni w swoich oblężonych domach przez wiele godzin. Czasami znaleźli sposoby na przełamanie ataku Rosjan i potajemnie przechodzili z jednego mieszkania do drugiego, lecz wiele ciał zostało znalezionych całkowicie zwęglonych. Tego typu zdarzenia A. Lieven podsumował w sposób następujący: „Pomimo ich niekorzystnej pozycji (...) najbardziej zadowoleni byli ci fanatycy, którzy myśleli, iż mogli zniszczyć/zabić niewiernych" ${ }^{\text {"1 }}$.

W tym miejscu w opinii autora, należy zwrócić uwagę na fakt, iż zarówno Szamil i Mansur byli miurydami z sufickiego bractwa Nakszbandija ${ }^{52}$.

Życiorys Szamila, obfituje nie tylko pasmem sukcesów na Kaukazie Północnym, ale także porażkami. Poszukując ich przyczyn można wyraźnie zauważyć, że zaczęły się one od wojny krymskiej (1854-1856), w któ-

\footnotetext{
51 A. Lieven, Chechnya: Tombstone of Russian Power, New Haven-Londyn 1998, s.308.

52 G.M. Hahn, Russia's islamic threat, New Haven-Londyn 2007, s. 236.
} 
rej Wielka Brytania i Francja poparły Imperium Osmańskie przeciwko Imperium Rosyjskiemu. Coraz głośniej mówiono, że państwa zachodnie i Turcy osmańscy pomagają ludom kaukaskim. Jednak brak umiejętności dowódców do zawierania sojuszy, przy upartości i heroicznym oporze rosyjskich obrońców Sewastopola oraz rosyjskie zwycięstwo nad Turkami w Kars, spowodowały, iż na Transkaukazji doprowadziły to do niczego. $\mathrm{Z}$ tym rozczarowaniem i wycieńczeniem po trzydziestu latach wojny nadzieje w szeregach kaukaskich górali zaczęły słabnąć. Zwolennicy Szamila pozostawili go. On sam, osaczony przewyższającą go armią rosyjską, przy jednoczesnym poczuciu beznadziejności, został zmuszony w 1859 r. do poddania się pod aułem Gunib w Dagestanie ${ }^{53}$. Już w końcu lat czterdziestych XIX w. car zaczął aktywnie „współpracować” z naibami, przekonując do siebie osoby z obozu Szamila za pomocą łapówek oraz obietnic. Ten fakt, a także transport wolnych żołnierzy z Krymu, doprowadziły do ostatecznej klęski wojskowej Szamila w 1859 roku, a sposób, w jaki został wzięty do więzienia jest godny uwagi i poświęcenia mu chwilki czasu. Otóż, na terenie pod jurysdykcją carską generała Bagrationiego, dla Szamila i jego rodziny zostały przygotowane dwa luksusowo urządzone w stylu kaukaskim namioty. W pobliżu tych namiotów, Szamil spotykał się z powagą z rosyjskimi generałami. Po jednym z tychże spotkań, Szamil z honorami został zesłany na wygnanie do miasta Kaługa, położonego niedaleko Moskwy ${ }^{54}$. Warto dodać, iż w 1869 r. odbył pielgrzymkę do świętych miejsca dla islamu, Mekki i Medyny za przyzwoleniem ówczesnego rosyjskiego cara. Zaś dwa lata później, czyli w 1871 r., zmarł w saudyjskim mieście Medyna i tam też został pochowany.

\section{Posłowie}

Należy wspomnieć raz jeszcze, że podczas wojen na Kaukazie Północnym będących oporem wobec rosyjskiego podboju w latach od 1785 do $1859 \mathrm{r}$. likwidowano muzułmańskich nauczycieli/liderów, takich jak: Szejk Mansur Uszurma, Kazi mułła czy imam Szamil, którzy odgrywali kluczową rolę przywódców politycznych, wojskowych oraz religijnych. Tworząc

\footnotetext{
53 A. Lieven, op.cit.

54 I. Rybkin, op.cit., s. 28.
} 
własne środowiska próbowali zjednoczyć ludy Kaukazu Północnego poprzez wdrożenie prawa szariatu w tym regionie (decyzja ta została niezatwierdzona przez niektóre czeczeńskie tejpy) ${ }^{55}$. W latach 1878-1891 wojna rosyjsko-turecka szejk mansur przeprowadził się do północno-zachodniego regionu Kaukazu Adygei, wzmacniając tamtejszą tradycję islamu. Aktywował i dowodził społecznością Adygei i Nogajów w atakach przeciwko Rosjanom, choć wiele z nich już na samym wstępie nie miało żadnych szans powodzenia. W czerwcu 1791 roku został aresztowany w tureckiej twierdzy Anapa nad Morzem Czarnym. Mansur został przywieziony do Sankt Petersburga i skazany na karę więzienia. Zmarł w więzieniu w roku 1794, stając się legendarnym bohaterem mieszkańców Kaukazu Północnego. Naznaczony przez Czeczenów Mansur uważany jest za ojca ruchu czeczeńskiego wyzwolenia, a jego dziedzictwo inspirowało polityczne zjednoczenie ludzi z Północnego Kaukazu ${ }^{56}$. Choć według opinii Galiny Jemalianowej, pierwszym był imam Kazi mułła, bliski współpracownik i zwolennik imama Jaragskija ${ }^{57}$. Gazawat zaczął się na południu Dagestanu, ale pod koniec lat 30. XIX wieku swoim zasięgiem objął większość Dagestanu oraz Czeczenii. Zaś po śmierci imama Kazi mułły, idee świętej wojny i przywództwo w dowodzeniu ludami północnokaukaskimi przeciwko Rosjanom przejął imam Gamzat bek. Natomiast od 1834 r. do 1859 r. góralami północnokaukaskimi dowodził legendarny przywódca imam Szamil, który zjednoczył Czeczenię i północny Dagestan w jedno państwo islamskie - Imamat, które przez ponad ćwierćwiecze z powodzeniem odpierało wojska rosyjskie i ich ekspansję na Północnym Kaukazie ${ }^{58}$. Mansur Uszurma oraz imam Szamil, to etniczni Awarowie (największa grupa etniczna współczesnego Dagestanu), którzy stali się punktem zapalnym i cały czas podsycali ogień buntu ${ }^{59}$.

Po zniszczeniu miejsc dowodzonych przez Szamila na obszarach Czeczenii i Inguszetii przez siły rosyjskie pod dowództwem generała Nikołaja Jewdokimowa, oddziałom Szamila ukazała się seria porażek zadanych

\footnotetext{
55 G.M. Hahn, op.cit., s. 31.

56 A. Askerov, op.cit., s. 3.

57 G. Jemalianowa, op.cit., s. 50.

58 Ibidem.

59 G.M. Hahn, op.cit., s. 95.
} 
przez carskie siły. Między innymi, poddając się latem 1859 roku spowodował zawładnięcie przez nich Dagestanu, a taki splot okoliczności okrył go hańbą. Nastąpił koniec 25 lat walk narodów połnocnokauaskich, gdzie przez tyle lat stawiali opór wobec nałożenia carskich imperialnych zasad, reguł ${ }^{60}$. Mansur Uszurma w 1791 roku dostał się do niewoli rosyjskiej, gdzie był uwięziony w twierdzy Schlusselburg, gdzie zmarł w $1794 \mathrm{r}^{61}$ Rosnąca kontrola nad Kaukazem Północnym zaczęła podlegać konsolidacji, a w 1860 roku, ogłoszono obwód dagestański. Opór ludności z Północnego Kaukazu był jednak uważany za jedną z ośmiu muzułmańskich wielkich militarnych opozycji wobec kontroli „niewiernych” i ich jurysdykcji i dał Awarom oraz mieszkańcom Dagestanu wielką dumę i jakąś pozycję w muzułmańskim świecie ${ }^{62}$. W tym miejscu autor chciałby dodać, że ma świadomość, iż podjęty temat nie do końca został wyczerpany, lecz żywi nadzieję, iż stanie się on inspiracją i będzie podżegał zarówno naukowców z ogromnym doświadczeniem, jak i adeptów do dalszych wnikliwych badań, dyskusji czy studiów dotyczących historii-roli jaką odgrywali w przeszłości przywódcy religijni na ziemiach dzisiejszej republiki dagestańskiej, czeczeńskiej i inguskiej. Czynniki historyczne z życia religijnych przywódców czeczeńskich, wyraźnie wskazują, że Mansur Uszurma, Kazi mułła, Gamzat bek czy imam Osman Szamil, to postacie o niezwykłej charyzmie, które znalazły i potrafiły nadać sens walkom przeciwko swoim zawziętym wrogom. Posiadając umiejętność trafnej oceny sytuacji celnie formułowali hasła narodowowyzwoleńcze połączone z zasadami islamu, które konsolidowały nie tylko naród czeczeński ale także inne ludy północnokaukaskie do podjęcia walki zbrojnej przeciwko rosyjskiemu kolonizatorowi. I choć skuteczność ich działań zbrojnych była różna, niefortunnym byłoby twierdzenie, że przywołani powyżej przywódcy byli nieudolnymi strategami, albowiem ich sukcesy i porażki raczej się bilansowały. Ponadto, winno się podkreślić, w jakiej atmosferze, i w jakich okolicznościach kształtowały się ich przekonania. Pomimo widocznej przewagi wojsk Imperium Rosyjskiego wspieranego przez Kozaków decydowali się na podjęcie walk. Dowodząc niewielkimi, niedozbrojonymi grupami ludów kaukaskich dzielnie

\footnotetext{
60 Ibidem.

61 H. Krech, op.cit., s. 11.

62 G.M. Hahn, op.cit., s. 95-96.
} 
stawiali czoła dobrze zorganizowanej, wielotysięcznej armii Imperium Rosyjskiego. Żadne z bolesnych doświadczeń nie podcięło im skrzydeł, a wręcz przeciwnie. Jeszcze bardziej mobilizowało. Ich świadome działania były wyzwaniem nie tylko dla nich samych, ale także stały się silnym bodźcem dla zbiorowości kaukaskiej (poza Kabardyjczykami, którzy w przeciwieństwie do Bałkarców oraz ich etnicznych braci Adygejczyków nie przystąpił do ruchu oporu wobec rosyjskiego podboju mającego miejsce w latach od 1824 do 1856 r. $)^{63}$. Dzięki ich przywództwu społeczność zrozumiała, że musi znaleźć w sobie siłę do przeciwstawienia się rosyjskim dygnitarzom; że chcąc być wolnym, muszą ryzykować to co mają najcenniejsze-życie. Świadectwo istnienia religijnych przywódców czeczeńskich, to rozbudzone ambicje górali i przedsięwzięcia zbrojne, które wielokrotnie budziły obawy Imperium Rosyjskiego.

\section{Bibliografia}

Askerov A., Historical Dictionary of the Chechen Conflict, Lanham 2015. Barrett M.T., At the edge of Empire. The Terek Cossacks and the North Caucasus frontier 1700-1860, Boulder 1999.

Hahn M.G., Russia's islamic threat, New Haven-Londyn 2007.

Jaimoukha A., The Chechens. A handbook, Londyn-Nowy Jork 2005.

Jemalianowa G., Russia and Islam. A Historical Survey, Nowy Jork 2002 [ebook].

Krech H., Der russische Krieg in Tschetschenien (1994-1996). Ein handbuch: Mit eine Sicherheitskonzept zur Einbindung der Russischen Föderation in die NATO und die Europaische Union, Berlin 1997.

Lacey R., Inside the kingdom: Kings, clerics, modernists, terrorists, and the struggle for Saudi Arabia, Londyn 2009.

Rybkin I., Consent in Chechnya, consent in Russia, [b.m.w.] 1998. s. 134 .

63 G.M. Hahn, Russia's islamic threat, Yale University Press, New Haven-Londyn 2007, 


\section{Chechen religious leaders from the $18^{\text {th }}$ to $19^{\text {th }}$ centuries}

\section{Summary}

The proposed topic is a focus on political and religious activity by religious leaders in the North Caucasus in the fight against the Russian colonizer. Under their leadership they sought victory over the Russian Empire. The author tried to present the most important and vital moments in the life of Mansur Ushurma, Kazi mullah, Gamzat bek and imam Osman Shamil too.

Keywords: Chechnya, Islam, Sufi, Shamil, Naqshbandi, Mansur, Kazi mullah, Gamzat bek

\section{Чеченские ремигиозные мидеры с 18 по 19 век}

\section{Абстракт}

ПреАлагаемая тема сосреАоточена на политическо-религиозной Аеятельности религиозных мидеров на Северном Кавказе в борьбе с русским колонизатором. ПоА их киАерством стремились к победе наА Русской Империей. Автор старался преАставить важнейшие и кмючевые решения, моменты из жизни таких религиозных глав как напр.: Мансур Ушурмы, Кази мулмы, Гамзат-бек и имама Османа Шамимя.

Кмючевые слова: Чечня, Ислам, Суфи, Шамиль, Накшбанди, Мансур, Кази мумла, Гамзат бек

dr Kamil Pietrasik

członek Towarzystwa Azji i Pacyfiku

kamilpietrasik@interia.pl 